\title{
Delivery models of local economic development: An analysis of internal and external models in Ontario
}

\author{
Stephen Thompson
}

\begin{abstract}
As the role of an economic development officer (EDO) continues to expand as a profession, the functions and services that an EDO is responsible for change. In recognizing a need to develop an organizational structure for the economic development office to respond to this transformation, this paper conducts a comparative advantage of the two most common economic development delivery models at the local-municipal level in Ontario: the municipal model of economic development, and the not-for-profit corporation model of economic development. The author concludes that neither model is superior since individual municipalities have different characteristics and priorities which help guide each individual municipality to the model that is best for its own circumstances.
\end{abstract}

Keywords: organizational structure, models of economic delivery, municipality, not-forprofit corporation.

\section{Introduction}

Economic development is a growing, yet relatively young profession in comparison to other municipal professions such as engineering and planning. Its roots are in the field of industrial development, which became organized in the last fifty years in Canada with the formation of the Industrial Developers Association of Canada (IDAC) in 1968, and the Ontario Industrial Development Council Inc. (OIDCI) in 1958. Both were subsequently renamed the Economic Developers Association of Canada (EDAC) and the Economic Development Council of Ontario (EDCO) (Economic Developers Association of Canada, 2009; Economic Developers Council of Ontario, 2009). The name change reflects the broadening scope of the profession, which may also include commercial, tourism, downtown renewal (Bryant and Preston, 1988) and other responsibilities such as branding and community development (Blais and Redden, 2009). According to membership directories of both EDAC and EDCO, membership continues to increase, indicating growth and recognition of economic development as a profession.

The growth in the profession enables many municipalities to hire several economic development employees to focus on activities such as business attraction, business retention and expansion, marketing, investment attraction, labour market development, and often tourism destination marketing and development. With this growth in functions and services provided comes the need to develop an organizational structure for the economic development office that connects it 
to the business community as well as the municipal council or administration, which typically is responsible for funding the local economic development office. The economic development office needs to have strong ties with city staff which help move through the development process. It also benefits from relationships with external organizations with similar roles in economic development. This may include the chamber of commerce, community development organization, small business centre, local associations such as a downtown association, educational, training and research institutions, and where possible, an upper tier of government such as a county or region (Bowen, Rubin, Hill, 1991).

The focus of this research is an examination of the two most common economic development delivery models at the local-municipal level in Ontario: The internal model where an internal department reports through the administration to municipal council, and the external model in which a not-for-profit corporation provides economic development services and is governed by a board of directors. Comparative advantages of each model will be introduced and a time series analysis will be presented to document trends of growth or decline in adoption of either model.

\section{Literature review}

Local municipalities largely exist to provide services (Bowen, Rubin, Hill, 1991). However, the era when municipal governments provided only the most basic services to property is long past (Myhal, 1993). The expanded delivery of municipal services and also municipal reform has often led to the establishment of external corporations. Often incorporated as agencies, boards, commissions, or corporations, they are introduced to enhance the delivery of municipal services through specialization (Richmond and Siegel, 1993).

A literature review reveals that the debate over internal and external municipal organizations is not a new construct Ontario. Boards of police were formed in Upper Canada in 1858, as were boards of health. In the nineteenth-century external organizations such as utility and planning commissions were formed to take those functions out of direct political control and place them under professional influence (Keating, 1991). Planning Commissions have since, generally been abolished and planning is now a function of the municipal political process, with politicians expected to be accountable to make planning decisions in public (Siegel, 1993a).

External organizations are typically created to provide a single service; provide a highly specialized service; allow for arm's length decision-making; separate the service from the political process; remove certain functions from the public eye; establish self-funding businesslike units; involve business people in decision-making; or to provide for multi-jurisdictional representation (Myhal, 1993). 
External organizations have proven to be effective and efficient to varying degrees (Richmond and Siegel, 1993). They have also proven to be contestable; external agencies are often seen as leading to fragmentation, hindering public understanding of government and often perceived to be less accountable (Graham, 1993). The basic conflict between flexibility and efficiency on the one hand, and accountability on the other, pervades many discussions on this topic (Myhal, 1993). There are, however, two obvious mechanisms to link municipal councils to external organizations: representation on the board and control of some portions of the organizations budget (Graham, 1993).

The design and implementation of appropriate structures and accountability practices can minimize these risks, yet the conventional wisdom in local government often calls for a reduction in the number of special purpose bodies (Richmond and Siegel, 1993; Graham, 1993). As early as 1980, the Association of Municipalities in Ontario has also indicated that it favours moving towards a reduction of special purpose bodies and a strengthening of the municipal council's role (Myhal, 1993).

Economic development is another local service that is, in certain instances, delivered by specialized, external, “quasi-public” economic development corporations, usually funded from a mixture of public and private money and reporting to a board of local political and business leaders (Bowen, Rubin, Hill, 1991). Thus, municipal organizational structure involving the economic development office has also been a topic of research and analysis on many occasions (Kitchen, 1985; Kallio, 1986; Bryant and Preston, 1988; Frith, 1993; Blais and Redden, 2009; Myhal, 1993; Bowen, Rubin, Hill, 1991; Siegel, 1993a). Many of these studies introduced the topic and went further to look at local/regional relationships, as well as the relationship between economic development and planning.

\section{Role of the economic development professional}

Before the organizational structure can be reviewed and discussed, it is beneficial to understand the role of the economic development professional. It appears there is no single definition of the role of economic development. Neither the Economic Development Association of Canada nor the Economic Developers Council of Ontario includes a definition of economic development in their by-laws. (Penny Gardner, Economic Developers Association of Canada, E-mail Communication, September $9^{\text {th }}$, 2009; Economic Developers Council of Ontario, 2009a) One of the most comprehensive definitions can be derived from the work of Bryant and Preston, 1988 which authored an entire Economic Development Bulletin including the following table of eleven typical functions of the economic development office:

1. Information development and transfer;

2. Local business retention and expansion; 
3. Attracting new investors and entrepreneurs;

4. Strategic economic planning;

5. Advocacy;

6. Encouraging foreign investment and entrepreneurial immigration;

7. Maintaining a public relations program for the community;

8. Participating in downtown revitalization;

9. Enhancing trade opportunities for local entrepreneurs;

10. Supporting small business and investors; and

11. Providing forecasting infrastructure for development.

A similar, although less specific definition was put forward by Bowen, Rubin, and Hill (1991) as an activity designed to stimulate economic growth by creating and retaining employment, improving income, strengthening and expanding the tax base, and fostering full use of available resources in the municipality. As well, researchers such as Frith (1993) have attempted to identify a central purpose to economic development. He infers that the principal role of the economic development professional has been to generate and maintain both local employment and the municipal tax base. Peterson (1981) and Kitchen both questioned the impact of many economic development programs. Kitchen (1985) went a step even further and conducted a review of the municipal economic development function in Ontario and evaluated whether there was merit in the role of local economic development - a debate not unheard of at budget time in council chambers across Ontario and beyond.

The debate over the role of economic development can be attributed to more than just the varied definitions of the profession. Local economic development professionals cannot control the destiny of their community. External factors and decisions by the private sector, which the economic development professional can only influence, make local economies extremely vulnerable to outside market forces. These conditions make it difficult to measure the impact of economic development tools in aiding business to expand or luring new business to the community (Bowen, Rubin, Hill, 1991).

Municipalities have the option to choose whether changes in the economy are simply allowed to occur unmanaged or whether it intentionally guides and manages "local responses" toward the goals of economic growth and development by establishing an economic development program in the community (Bowen, Rubin, Hill, 1991). This program is generally designed to align with the desire of the municipality to attain an optimum population size to provide the services desired by their population at a minimum cost (Keating, 1991).

However, indications are that the economic development profession in Ontario and Canada continues to grow (Economic Developers Association of Canada, 2008). This growth may be an indicator that the desire of municipalities is to be actively engaged in their economic future. 
Bryant and Preston (1998) state "if municipalities wish to maintain and develop their role in the economic development process, they must realize that the EDO [economic development professional] is their star player..." It may be this highly visible position and perceived role in the "quality of life" in a community that also makes the economic development professional highly vulnerable. Perhaps central to this vulnerability is the fact that economic development programming such as trade shows, external advertising, etcetera is much more resource intensive than other municipal activities such as development approvals.

It is the role of the economic development professional that appears central to much of the published material relevant to this research into the structure of the economic development office. Frith titled his 1993 thesis “Analysis of Organizational Structure of Local Economic Development in Ontario" and focused his research on the costs and benefits of integrating the economic development office with the planning department. From one-on-one interviews with 20 economic development professionals in Ontario, his research identified a number of key points that are transferable for consideration to the municipal model of economic development versus the not-for-profit corporation model.

Frith (1993) states that there are many resources that could be shared between the planning and economic development departments, such as a land inventory and demographic data. He finds that the planning and economic development disciplines may be closer in practice than ever before but that perhaps it is the economic development practice that has come closer to planning rather than the planning practice that has gravitated closer to traditional economic development.

Frith summarizes that "while the work of municipal planners and local EDOs has been well detailed in various sources, there is an absence of written work concerning the relations between the two agencies" (p. 66) and that there is general agreement among different authors that there should be greater co-operation between planning and local economic development, but that economic development and planning organizations should be separate.

The results of Frith's analysis indicate that approximately 33 percent of economic development offices were combined with the planning department, and that combined departments were generally associated with municipalities with smaller populations. Frith identified several key differences between the two organizational structures including improved perception by the private sector of separate economic development offices, as well as better communication with the private sector. Frith categorized the benefits of merging the economic development office with the planning department to be internally focused such as cost, reporting, and data collection efficiencies.

As Frith acknowledged, his analysis took into account lower-tier municipalities such as cities and upper-tier municipalities such as counties or regions. However, one might argue that these 
should be analyzed separately because of the different roles that lower and upper-tier governments play in both planning and economic development. Possibly a greater limitation of Frith's work is that it included both economic development corporations and economic development departments in the analysis without clear differentiation. Naturally, a separate economic development corporation couldn’t be part of a municipal planning department.

Earlier research by Kitchen (1985) included a survey of 57 economic development organizations in Ontario to determine their reporting relationships. This identified six options to which local economic development offices report: Chief Administrative Officer, Board of Directors, Committee/Commission, Planning Commissioner, Mayor, or Council. Kitchen also reported that the data he compiled from a 1983 Ontario Industrial Development Council (now the Economic Developers Council of Ontario) Budget and Salary Survey report indicated that 35 percent of economic development organizations were either independent corporations or commissions. This research, however, did not organize economic development organizations by level of government, nor by population of area served. As well, advisory boards may have been classified into the board of director's category, which would prevent this category from being an accurate indicator of a corporation structure.

A good summary of several considerations relevant to this debate is presented by Bryant and Preston (1988). The authors affirm the importance of reporting relationships in economic development. They state "The organizational structure which the EDO operates is important because economic developers must have access to policy and decision makers.” Bryant and Preston quote that "The less direct the reporting relationship, the less effective the development officer will be; and the less input and output he will receive from the decision making process." Also key is the ability of the economic development professional to sell the ideas contained in the strategic economic plan to senior levels of government. Presentations and reports on plans and project development must be convincing and gain their support because successful development requires local political commitment and sufficient levels of funding.

Bryant and Preston also highlight the importance of the alignment of the economic development officer with the business community and suggest the economic development officer be central to the creation of the economic development and community strategy. Richmond and Siegel (1993)

suggest that there is a trend in local governments to initiate more advisory bodies to stimulate the consultation process and improve public input while maintaining council's control. This may possibly apply to economic development as well.

\section{Models of economic development}

There are two primary models of Economic Development Offices. They are either the internal municipal model or the external not-for-profit corporation model. 
In the internal model of economic development, staff members are accountable to Council for the delivery of economic development programming. The economic development office may be either a stand-alone department or integrated with another department such as the planning department (Frith, 1993). Policy is set by Council and staff members are employees of the municipality. In smaller municipalities, economic development activities may be the responsibility of the clerk, city manager/chief administrative officer, planner, or economic development officer. Budgetary constraints in smaller municipalities may limit the economic development activity to a part-time responsibility of an individual in another department. Committees of council or advisory bodies are so close to the core municipality that they should not really be considered a separate entity (Siegel, 1993a) and therefore economic development offices with committees of council or advisory bodies are classified in this research as following the internal model.

In the external model, a not-for-profit corporation exists and staff members report to the board of directors of the corporation often through a General Manager/Chief Executive Officer (CEO). The board of directors is accountable to obtain funding for payroll, and operations including programming. Most of this funding is generally from the municipality. A rudimentary analysis conducted in 2007 found that 85 percent or more of the revenue of most not-for-profit corporations come from the municipality in the form of operating grants (McCabe, 2007). The remainder of the budget was achieved from federal/provincial grants and fundraising including sponsorship, gala dinners, golf tournaments, etcetera. In the external model, the board of directors sets policy and staff members are employees of the corporation. The separation from municipal operations would likely indicate that the staff members focus on economic development activities without distraction by other municipal matters. The board of directors would typically include the majority of members drawn from the business community plus several members of council. A corporation is not under the direct control of the municipal council, but is one step removed from the municipal administration (Siegel, 1993a).

Advisory committees are common in both structures. They serve the purpose of engaging the private sector in guiding topic or sector-based discussions, for example the industrial sector or the tourism sector. These committees also typically include several members of council with the majority of members drawn from the development and business community. Committees are typically created to provide strategic direction on economic development matters and especially in the case of municipal economic development offices, to create a link to the private sector. When employed by a municipal economic development office this is sometimes called a hybrid model, however, it may be more accurately a variation on the municipal model since policy is set by council and staff are employees of the municipality. The advisory committee does not deal with matters of human resources, finance, information technology, etc. Instead, it focuses on strategic matters pertaining to economic development (McCabe, 2007). 


\section{Comparative advantages}

With each structure, whether the internal or external structure, a number of pros and cons can be found. In an effort to assemble a comprehensive list of the comparative advantages of each model, in December, 2008, members of the Economic Developers Association of Canada and the Economic Developers Council of Ontario were invited by e-mail, to provide information on the advantages, disadvantages, strengths or weaknesses associated with having an economic development department (internal model) versus an economic development corporation (external model). The purpose of this was to gather feedback and assemble a comprehensive list of the pros and cons of economic development offices structure throughout the country.

From this communication with members of both associations came nineteen responses. Of these, five came from municipalities in Ontario, three from municipalities in British Columbia, two from municipalities in Alberta, and one municipality from Manitoba. One response was received from members in each of Quebec, Newfoundland and Labrador, Nova Scotia, New Brunswick, and Prince Edward Island. In addition, three responses came from individuals working in consulting firms in Ontario.

The responses received, for the most part, contained information on how each respondent's municipality has structured the economic development office and the successes and limitations each community experienced as a result of its model. Several respondents were from communities that had recently changed its model of economic development and were therefore able to speak to the pros and cons of each model from first-hand experience.

The advantages from responses received have been organized into the frequency tables (Tables 1 and 2).

The advantages of each model are explained in more detail in the two sections below. The first contains information on advantages of the not-for-profit economic development corporation model of economic development and the second section on advantages of the municipal model of economic development.

Table 1: Frequency table - external model advantages

\begin{tabular}{|l|l|l|}
\hline & Number of & Percent of \\
\hline Private-Sector & 6 & $32 \%$ \\
\hline Focus & 5 & $26 \%$ \\
\hline Funding & 3 & $16 \%$ \\
\hline Aggressive and & 3 & $16 \%$ \\
\hline
\end{tabular}




\begin{tabular}{|l|l|l|}
\hline Timely and Responsive & 3 & $16 \%$ \\
\hline Streamlined Decision & 3 & $16 \%$ \\
\hline Policies & 2 & $11 \%$ \\
\hline Full Cost Accounting & 2 & $11 \%$ \\
\hline Separate Finances & 2 & $11 \%$ \\
\hline Confidentiality & 2 & $11 \%$ \\
\hline
\end{tabular}

Table 2: Frequency table - internal model advantages

\begin{tabular}{|l|l|l|}
\hline & Number of & Percent of \\
\hline Municipal Collaboration & 6 & $32 \%$ \\
\hline Access to Municipal & 6 & $32 \%$ \\
\hline Alignment with Council & 6 & $32 \%$ \\
\hline Streamlined & 4 & $21 \%$ \\
\hline $\begin{array}{l}\text { Branding and Municipal } \\
\text { Communication }\end{array}$ & 2 & $11 \%$ \\
\hline Stability of Funding & 4 & $4 \%$ \\
\hline
\end{tabular}

\section{External model advantages}

An external corporation has the benefit of being more closely aligned with business and industry. The external model fosters working practices that are more closely aligned with the private sector than those of the public sector. A corporation provides the opportunity for business leaders to become fully engaged and accountable through membership on the board or leading activities and initiatives (McCabe, 2007). Boards of external organizations allow for the presence of outside expertise or for the representation of a number of groups or interests. Expertise can be provided by members of the board and having representatives of certain specific organizations on the board can effect coordination between agencies (Myhal, 1993). As well, stakeholders may be more likely to get involved and assist an external economic development office (Peterson, 1981). Many organizations use volunteers to provide services which would cost thousands of dollars of employees were hired instead. While people are frequently enthusiastic about volunteering for certain agencies, not as many volunteer to work for their local government. And if they did, there could be problems with established employees and unions (Myhal, 1993).

In the external model the corporation can be an aggressive and competitive advocate on behalf of an investor to ensure the municipal functions such as planning and engineering are being proactive and responsive. Operating as a separate corporation enables staff to conduct business 
differently than a municipal office does; for instance being more aggressive and taking risks when it comes to business or marketing decisions.

A corporation offers the autonomy and provides ability to operate with a minimum of bureaucracy. This is particularly important in an economic development office which often requires fast-paced decision-making in an environment of constantly shifting priorities based upon client needs. The separation in reporting structure helps ensure focus remains on economic development rather than becoming a special projects department or one assigned projects that don't fit with any other department such as capital projects, municipal real estate matters and tenancy agreements.

A corporation has the ability to have its own set of policies including pay scales and labour policies which can be tailored to align best with the nature of the work of the employees. Hours of work can be adjusted to match those of the private sector to improve access to information and resources.

A corporation provides full-cost accounting; all expenses associated with the corporation are accounted for including rent, office equipment, phone expenses, computers, postage, reception, etcetera. The corporation, which has a separate set of financial records, has the ability to carry forward surplus or deficits from year to year. This is particularly important for an organization that relies heavily on grant or other revenues, which can reduce the need for transfers from the municipality, or savings can benefit operations in future years. This method of operations also provides a separation from "spend it or lose it” syndrome.

As well, being a separate entity allows economic development corporations to apply for funding from sources that might be unavailable if the entity was a city department. While in some instances funding may still be available, if that funding is staffing related, municipal collective agreements may present a barrier.

In the external model client confidentiality was cited as a strength. However, it may be the case that the leadership in either model (board of directors in the external model or council in the internal model) may request involvement in confidential client matters. As well, Frith (1993) suggested that confidentiality is often "a crutch" used by economic development offices to avoid integration with other municipal functions.

\section{Internal models advantages}

Incorporating the functions of the corporation into the structure of the municipality has the opportunity to streamline administration through integration with council meetings, thereby eliminating board meetings and the associated administration, incorporation of finances with city 
operations, eliminating a separate set of audited books and administration. It can also eliminate confusion or red-tape (Myhal, 1993).

Operating as a department also offers the potential to increase collaboration between departments and economic development staff. A separate corporation structure inevitably leads to a degree of isolation of the corporation and stereotyping of it as an outside body and thus less of the "city team". When integrated with the municipality the economic development office is better able to facilitate development and business issues.

The integration of economic development office functions into the municipal structure provides the opportunity for greater involvement in communications and marketing. Marketing within a corporation would be primarily focused on marketing associated with economic development and tourism and less on community services/activities and other “City Hall news” or overall community branding.

When integrated as a city department rather than a stand-alone corporation, policy and direction are streamlined and municipal protocols can be adopted regarding committees and appointments. Accountability to the electorate is directly through the council process. Municipal departments generally garner more public attention and therefore may be held more accountable than external organizations (Myhal, 1993). With a separate corporation, the board sets policy and direction which may or may not always directly align with the policy of council, which can lead to significant conflict - it can be difficult to serve several masters (Myhall, 1993). As well the economic development strategic plans can be more directly integrated with other municipal strategic plans.

In the internal model, funding is generally from the municipality with less expectation for staff to source private-sector funding. The potential for more sustainable wages, benefits, and pensions can help attract and retain highly-skilled economic development professionals.

When part of the municipal function, it gains access to established municipal services including human resources, finance, geographic information systems, etcetera and enables the economic development office to deliver programs that require coordination across multiple departments.

\section{Comparison of the external and the internal model}

The external and internal models exist to achieve the same general purpose: the provision of local economic development services. The models have a series of considerations which inherently connect to the advantages and disadvantages of each. An advantage in one model often aligns with a disadvantage in the other model. Table 3 compares key operational differences between the two models. 


\section{Time series analysis}

This analysis focuses on the local municipalities in Ontario with a minimum population of 15,000 people. These municipalities, which are typically called a city, a town, a township or a village, are classified in the 2006 Statistics Canada Census as either lower-tier municipalities or single-tier municipalities. Single-tier municipalities are those where there is only one level of municipal government in that area, such as the City of London or City of Toronto.

Lower-tier municipalities are those within a higher level of municipal government such as a county or region such as the City of Mississauga, which is in the Region of Peel. Counties and regions are not part of this analysis. However, several former counties retain the word "county" in their name even though they are now single-tier municipalities. An example is Haldimand County, which is single-tier municipality and therefore part of this analysis.

Table 3: Operational Characteristics

\begin{tabular}{|c|c|c|}
\hline & External Model & Internal Model \\
\hline Alignment & $\begin{array}{l}\text { Ability to be well connected with the } \\
\text { business community with the private } \\
\text { sector represented on the board. } \\
\text { Potentially disconnected from } \\
\text { municipality and council. }\end{array}$ & $\begin{array}{l}\text { Potentially disconnected from } \\
\text { business community. } \\
\text { Potential for a stronger working } \\
\text { relationship with departments such } \\
\text { as the planning department. }\end{array}$ \\
\hline Autonomy & $\begin{array}{l}\text { Ability to work with a minimum of } \\
\text { bureaucracy in an environment that } \\
\text { often requires fast-paced decision- } \\
\text { making. However, items requiring } \\
\text { board attention between meetings } \\
\text { need to be handled by GM/CEO due } \\
\text { to limited frequency of meetings. }\end{array}$ & $\begin{array}{l}\text { Structured decision making } \\
\text { framework involving } \\
\text { committee/council process. }\end{array}$ \\
\hline Coordination & Viewed as an external stakeholder. & $\begin{array}{l}\text { Ability to access city resources and } \\
\text { coordinate projects across } \\
\text { departments. }\end{array}$ \\
\hline Policies & $\begin{array}{l}\text { Ability to have its own set of policies } \\
\text { reflecting the nature and needs } \\
\text { associated with the Corporation's } \\
\text { activities. }\end{array}$ & City policies prevail. \\
\hline Focus & $\begin{array}{l}\text { Ability to set the focus of activities } \\
\text { on the core priorities identified } \\
\text { through an economic development } \\
\text { strategy. }\end{array}$ & $\begin{array}{l}\text { Projects that don't fit with any other } \\
\text { department such as information } \\
\text { technology, capital projects, } \\
\text { municipal real estate matters, and } \\
\text { tenancy agreements may be assigned }\end{array}$ \\
\hline
\end{tabular}




\begin{tabular}{|c|c|c|}
\hline & & $\begin{array}{l}\text { to the economic development office, } \\
\text { making it more of a special projects } \\
\text { office. }\end{array}$ \\
\hline $\begin{array}{l}\text { Full Cost } \\
\text { Accounting }\end{array}$ & $\begin{array}{l}\text { Expenses such as rent, equipment } \\
\text { rentals, phone expenses, computers, } \\
\text { postage, reception attributed with an } \\
\text { individual department are born by the } \\
\text { corporation. }\end{array}$ & $\begin{array}{l}\text { Expenses such as rent, equipment } \\
\text { rentals, phone expenses, computers, } \\
\text { postage, reception attributed with an } \\
\text { individual department are generally } \\
\text { not assigned back to that cost centre. }\end{array}$ \\
\hline Accounting & $\begin{array}{l}\text { Financial overruns and under runs } \\
\text { stay with the corporation. Surplus or } \\
\text { debt from one fiscal year } \\
\text { automatically gets carried from one } \\
\text { fiscal year to the next. }\end{array}$ & $\begin{array}{l}\text { Ability to cover financial overruns } \\
\text { by savings in other departments. } \\
\text { Financial savings may fund overruns } \\
\text { by other departments. Less } \\
\text { incentive to exercise fiscal } \\
\text { responsibility. }\end{array}$ \\
\hline Risk taking & $\begin{array}{l}\text { The board of a corporation may } \\
\text { choose to respond to opportunities } \\
\text { with a greater ability to be aggressive } \\
\text { and bold in its response. }\end{array}$ & $\begin{array}{l}\text { The bureaucratic process introduces } \\
\text { additional checks and balances to } \\
\text { limit risky decisions or to control } \\
\text { aggressive marketing. }\end{array}$ \\
\hline $\begin{array}{l}\text { External } \\
\text { funding }\end{array}$ & $\begin{array}{l}\text { Some funding programs are not } \\
\text { available to municipalities but are } \\
\text { available to non-profit corporations. } \\
\text { Municipal funding clearly sets who } \\
\text { the economic development office is } \\
\text { accountable to. }\end{array}$ & $\begin{array}{l}\text { Some funding programs are not } \\
\text { available to municipalities but are } \\
\text { available to non-profit corporations. } \\
\text { Greater expectation of sourcing } \\
\text { external funding. }\end{array}$ \\
\hline Admin. & $\begin{array}{l}\text { Administration is handled by } \\
\text { Corporation staff including the } \\
\text { scheduling of meetings, distribution } \\
\text { of reports, recording of minutes, and } \\
\text { maintenance of corporate records. A } \\
\text { separate set of audited books exists } \\
\text { and the associated costs. } \\
\text { Limited council input on business } \\
\text { plan and activities. }\end{array}$ & $\begin{array}{l}\text { Administration is streamlined } \\
\text { through integration with council } \\
\text { meetings, thereby eliminating board } \\
\text { meetings and the associated } \\
\text { administration, incorporation of } \\
\text { finances with City operations, } \\
\text { eliminating a separate set of audited } \\
\text { books and administration. } \\
\text { Council has direct input on business } \\
\text { plan and activities. }\end{array}$ \\
\hline Collaboration & $\begin{array}{l}\text { A separate corporation structure } \\
\text { inevitably leads to a degree of } \\
\text { isolation of the corporation and } \\
\text { stereotyping of it as an outside body } \\
\text { and thus less of the "city team”. }\end{array}$ & $\begin{array}{l}\text { Operating as a department also } \\
\text { offers the potential to increase } \\
\text { collaboration between departments } \\
\text { and economic development, tourism } \\
\text { and events staff. }\end{array}$ \\
\hline
\end{tabular}




\begin{tabular}{|l|l|l|}
\hline Marketing & $\begin{array}{l}\text { Marketing activities are primarily } \\
\text { focused on marketing associated with } \\
\text { economic development, tourism, and } \\
\text { special events and less on community } \\
\text { services/activities and other “city hall } \\
\text { news". }\end{array}$ & $\begin{array}{l}\text { Opportunity for greater involvement } \\
\text { in communications and marketing. }\end{array}$ \\
\hline $\begin{array}{l}\text { Access to } \\
\text { Municipal } \\
\text { Expertise } \\
\text { (HR, IT, etc) }\end{array}$ & $\begin{array}{l}\text { Generally limited or no access to city } \\
\text { expertise. }\end{array}$ & Ability to access city expertise. \\
\hline Contracting & $\begin{array}{l}\text { Contracts, with vendors, if multi- } \\
\text { year, typically do not extend beyond } \\
\text { the term of council. Generally the } \\
\text { term of the board members is } \\
\text { staggered and there is no change-over } \\
\text { of the entire board at once. }\end{array}$ & $\begin{array}{l}\text { Contracts with vendors, if multi- } \\
\text { year, typically do not extend beyond } \\
\text { the term of funding by council. }\end{array}$ \\
\hline
\end{tabular}

A total of 98 local municipalities were identified that met these criteria. A number of considerations lead to this delineation, including the following:

Municipalities with less than 15,000 in population may have less consistently had an internal or external employee that was a member of EDCO. As well, the municipal amalgamation in 2001 had significant impacts on the number, size, and naming of smaller municipalities making it particularly difficult to compare these municipalities from 1999 to subsequent time periods in this analysis. For those two reasons these municipalities were not included as part of this analysis. Hollick and Siegel (2001) noted a decrease in the number of small and an increase in the number of larger municipalities in Ontario over this period.

EDCO membership was chosen as a means to identify the presence of an internal or external economic development function in the municipality. This was chosen not just due to the availability of this data, but also as a means to qualify the level of staffing in economic development. One might be hard-pressed to find a municipality that would indicate it does not have economic development staff. However, these staff might be a mayor, city manager, engineer or other individual who has a multitude of other responsibilities. The presence of an EDCO membership probably indicates some level or formalization of involvement in economic development that might not be present in municipalities without an EDCO member.

To conduct this analysis, EDCO membership lists from 1999, 2004, and 2009 were reviewed for each of the municipalities in the analysis. The presence of an EDCO member working for a local municipality (internal) or a not-for-profit economic development corporation (external) which 
represents an individual local municipality was noted for each municipality in each time period (Appendix A).

Where the information in the EDCO directory did not clearly identify whether the economic development office was part of a municipal department or a stand-alone corporation, municipalities (nine) were contacted directly for the information.

\section{Observations}

A number of the municipalities examined as part of the analysis, have economic development services provided at a regional level of government. This is the case in regional areas such as Niagara, Durham, York, and others. In many cases, economic development services are also provided at the local level of government in those areas. However, only local and single-tier municipalities or agencies with EDCO memberships were classified through this study as having municipal or corporate economic development offices.

As well, some municipalities contribute to the funding of multi-municipal partnerships. Such is the case with the Greater Peterborough Economic Development Corporation which is funded by two municipalities: the single-tier City of Peterborough, and the upper-tier Peterborough County which includes the smaller municipalities surrounding, but not including, the City of Peterborough. Another example is the Windsor-Essex Development Commission, which provides economic development services across eight municipalities that were part of this analysis. Because economic development services are not provided the local level in those municipalities, they could not be classified into either the municipal or corporate categories.

Six municipalities were found to have economic development corporations in all three periods of the study. These municipalities were: London, Fort Erie, Kingston, Sault Ste Marie, St. Thomas, and Timmins.

The analysis also found a number of municipalities that changed structure over the three periods of the study. These changes were as follows:

- In 1999 Oakville was transitioning from having a municipal economic development office to a corporation structure, however by 2009 the office returned to being a municipal department.

- The Economic Development office in Burlington became a corporation between 1999 and 2004.

- Port Colborne's economic development office became a corporation between 2004 and 2009. 
- In the former Regional Municipality of Haldimand Norfolk, economic development offices moved from the upper- and lower-tiers of government to the new single-tier Haldimand County and new single-tier Norfolk County.

- Midland previously contracted economic development services from its area chamber of commerce but by 2009 municipal departments such as the planning department have these responsibilities.

Municipal Amalgamation in 2001 affected many of the municipalities in the study. This affected the comparability of data from the 1999 to 2004 and 2009 time periods. With the merging of lower- and upper-tier governments through the amalgamation process, economic development offices moved from the regional to the single-tier level in municipalities including Sudbury and Hamilton. Sudbury's economic development office followed the corporate structure in 1999, moving to a department model by 2004. Hamilton's economic development office remained a municipal department through the study period.

Sarnia has an economic development function within city departments, but marketing and other services are provided by the Sarnia Lambton Economic Partnership, which is regional in nature. This structure is unchanged through the three periods of the analysis. Given the focus of this analysis on local municipalities, the City's municipal economic development office is classified through this analysis but the larger Sarnia Lambton Economic Partnership is not.

\section{Results}

Table 4 summarizes the results of the analysis of delivery model used by 98 local municipalities in Ontario for economic development services.

Table 4: Delivery model analysis results

\begin{tabular}{|l|l|l|l|}
\hline Delivery Model & 1999 & 2004 & 2009 \\
\hline External & 9 & 8 & 8 \\
\hline Internal & 52 & 62 & 65 \\
\hline Outsourced & 1 & 1 & 0 \\
\hline Subtotal & 62 & 71 & 73 \\
\hline$\%$ of total & $63 \%$ & $72 \%$ & $74 \%$ \\
\hline
\end{tabular}

The study revealed that there is little change in the number of external local economic development offices; there were nine in the first period of the study and eight at the end of the study. However, only six were consistently operated externally throughout the study, with others changing in structure either becoming internal (departments) or external (corporations), or in the case of Oakville, becoming a corporation and returning to a city department all within the time periods of this study. 
The study indicated that there is an increase in the number of municipalities as part of this study with economic development staff as members of EDCO. In 1999 there were 53 internal economic development offices with EDCO members. This increased to 65 with members in 2009. Municipal amalgamation may have influenced this; amalgamated municipalities may have reached the critical size to warrant (or be able to budget for) staff with a role in economic development. Amalgamation may have also impacted the accuracy of the analysis since not all municipalities in 1999 remained comparable in population or geographic area following 2001 amalgamation.

The overall number of municipalities with an EDCO membership held by an internal or external economic development office increased from 63 percent to 74 percent throughout the study. This growth was entirely from within memberships held by employees of internal economic development offices - the number of external memberships did not increase. This may indicate overall growth of the economic development profession in Ontario as evidenced by the overall growth of municipalities' local economic development offices. The number of external economic development offices throughout the study did not increase and therefore did not keep pace with internal economic development growth.

In analyzing these results, consideration should be noted that the scope of activities of each economic development office might vary significantly. This could impact the appearance of the internal economic development function but may be less likely to do the same within the external corporations sampled. Corporations typically have staff members that are dedicated to economic development and possibly tourism whereas a number of municipalities list only a planner, city manager, or clerk as having an EDCO membership. If this is the only individual on staff involved in economic development, the municipality's total resources going toward economic development may be very limited.

\section{Future research}

From the review of the EDCO directories from 1999, 2004, and 2009, it appears that there may be a greater number of EDCO memberships being held by a position within the municipality with an economic development professional title. Future research could explore whether this indicates a growth in the economic development profession and staffing within communities, or whether this represents a change in which municipal position holds the EDCO membership.

Suggestions were received from some of the municipalities contacted suggest that there may have been a greater change in economic development structure in the five years prior to the period of this study (between 1994 and 1999). This time period was not part of this study for several reasons, including the above-noted consideration of comparability resulting from 
municipal amalgamation, and also for the fact that the Economic Developers Council of Ontario was not able to provide membership directories prior to the 1998 directory. However, if data sources are found, or if direct research with municipalities is undertaken, this may be an option for future research.

Several communities, particularly in the 1999 directory, listed the economic development office as an economic development commission. Through direct contact with those municipalities it was clarified whether these were a function of the municipality or rather a corporation. Further research could be conducted as to the reasons behind the naming of the economic development office and whether it is merely a name change or indicative of other structural characteristics of the office.

This study does not attempt to quantify the staffing level within the economic development office, nor the reporting structure of the municipal economic development function. It appears that some economic development offices are part of the CAO's office, others report directly to council, others may be part of another department such as planning or may be limited to part of one individual's time within another department. Further research could be conducted to analyze these characteristics. It could also document the presence of what is sometimes termed a "blended-model," which involves an economic development advisory committee that may make recommendations to staff and/or council.

Opportunities exist for further analysis of the structure and presence of regional economic development offices across Ontario. Indications are that many exist, but that they may range in organization from local municipalities in a certain geographic area which have agreed to collaborate on certain initiatives, to county/regional offices of economic development, to multijurisdictional entities that may receive funding from two or more single-tier municipalities, to Community Futures Development Corporations that may or may not provide economic development services typical of a municipal economic development office.

The entire analysis, or the above future research areas, could also be expanded to other provinces or jurisdictions outside Ontario which would capture additional models of economic development and regional districts such as in Western Canada, or regional partnerships such as in Eastern Canada.

\section{Conclusion}

There exist a number of delivery models of local economic development. These models can be generalized into two categories: the municipal model of economic development, and the not-forprofit corporation model of economic development. In both models, an additional characteristic found through the survey of members of the Economic Developers Association of Canada and 
the Economic Developers Council of Ontario, is the presence of economic development advisory committees.

The time-series analysis involved an review of 98 local municipalities in Ontario with a population over 15,000. The analysis documented that of the municipalities surveyed, 63 percent had a member of the Economic Developers Council of Ontario working at the local-municipal level in 1999. This grew to 72 percent in 2004 and 74 percent in 2009. The growth was entirely from municipalities engaged in the municipal model of economic development. The corporate model did not keep pace with this growth, declining from 9 instances in the first period of the study to 8 at the end of the study.

The study identified a number of advantages to each model. Among the most compelling arguments for an economic development corporation appeared to be not just the connection with the business community, but the engagement of the business decision-makers in setting the direction of the corporation as members of its board of directors. One of the strongest arguments in support of the municipal model of economic development appeared to be the internal alignment with council, the planning department, and other municipal departments.

Either model has the potential for the involvement of advisory committees. A review of literature found reference to the involvement of the business community in the economic development office. An economic development advisory committee may help this cause, especially for municipal economic development offices. As with the not-for-profit corporation model, a clear set of terms of reference will be needed for the advisory committee to define roles and responsibilities in the decision making process and to minimize conflict (Richmond and Siegel, 1993).

Which model is best, or as Frith asked, "Is one particular organizational structure the best choice for all municipalities or are different structures best suited for particular kinds of municipalities?" Either model of economic development comes with its own series of advantages. Ultimately the success factor of either model may be the decision making process: Does the municipality wish to be directly involved in the operation of the economic development office (municipal model) or does it wish for members of the private and public sectors to come together as directors of the board for a not-for-profit corporation? If the latter, how is the corporation made as accountable as possible to the municipality? (Graham, 1993). Since the economic development office is largely funded by the municipality, this factor, and also consideration of the other comparative advantages will ultimately be a decision of council.

This study was designed to introduce readers to the trends and comparative advantages of two models of local economic development delivery. It is intended that this study will help practitioners, municipal administration, and elected officials decide which of the two structures 
evaluated is best suited for their municipality. Neither model was determined to be superior since it is recognized that individual municipalities have different characteristics and priorities which will help guide each individual municipality to the model that is best for its own circumstances.

\section{Author Biography}

Stephen Thompson is the General Manager for the Port Colborne Economic \& Tourism Development Corporation in Port Colborne, Ontario. Since joining the Corporation in 2007, Stephen has worked to develop a number of new initiatives to assist in Port Colborne's economic future including business attraction, retention, marketing and tourism destination development programs. He also led the development of Port Colborne's Competitive Analysis and its first Economic Development Strategy and Action Plan.

Under his leadership, the Corporation has secured more than \$1.25 milllion in external funding. Recently Stephen managed the $\$ 350,000$ restoration of historic Humberstone Hall to establish a new visitor information centre and a new partnership with the Port Colborne-Wainfleet Chamber of Commerce.

Stephen also has experience operating a small business, and working in local, regional and provincial levels of government in both planning and economic development. Stephen is a graduate of the University of Waterloo and has degrees in Environmental Studies /Geography and a Masters degree in Local Economic Development.

In addition to his duties as General Manager, he is also director of Economic Development for the City of Port Colborne. As well, Stephen serves on the board of directors of the PortColborne-Wainfleet Chamber of Commerce and Ontario Agrifood Technologies (OAFT) and a number of committees- and is an active member of the Economic Developers Association of Canada and Economic Developers Council of Ontario.

In his time away from work, Stephen is an avid nature and landscape photographer and enjoys time at the cottage.

\section{References}

Blais, Paul \& Redden, Andrew. (2009, February). Investing in economic development: Important key indicators municipalities should assess. Municipal World.

Bowen, William, Rubin, Herbert \& Hill, Edward Hill. (1991). Management of economic development. Managing Local Government: Public Administration in Practice. Newbury Park, UK: Sage Publications Inc. 
Bryant, Christopher R. \& Preston, Richard E. (1988). The local economic development officer: The job and its role in the community. Economic Development Bulletin. (No. 4), Waterloo: University of Waterloo.

Economic Developers Association of Canada. (2008). 2007 Annual report. Flamborough, Ontario: Economic Developers Association of Canada.

Economic Developers Association of Canada. (2009). EDAC history. Flamborough, Ontario: Economic Developers Association of Canada. Accessed from http://www.edac.ca/html/shtml/edac_about_history.shtml.

Economic Developers Council of Ontario. (1999). 1998-1999 EDCO membership list by municipality. Canada’s Business Centre. Ontario. Richmond Hill: Kenilworth Publishing Inc.

Economic Developers Council of Ontario. (2004). Economic Developers Council of Ontario Member Directory. Oakville: Perspective Marketing.

Economic Developers Council of Ontario. (2009). 2009 EDCO Directory. Toronto: BCS Group.

Economic Developers Council of Ontario. (2009). By-laws - EDCO. Cornwall: Economic Developers Council of Ontario. Accessed from www.edco.on.ca/en/about/ByLaws.asp.

Economic Developers Council of Ontario. (2009). History - EDCO. Cornwall: Economic Developers Council of Ontario. Accessed from http://www.edco.on.ca/en/about/History.asp

Frith, Stephen. (1993). Analysis of organizational structure of local economic development in Ontario (MA Thesis). Waterloo: University of Waterloo.

Graham, Katherine. (1994). Agencies, boards and commissions: A taxonomy and the beginnings of an evolution. Agencies, Boards, and Commissions in Canadian Local Government. Toronto: Institute of Public Administration of Canada

Hollick, Thomas R. \& Siegal, David. (2001). Evolution, revolution, amalgamation: Restructuring in three Ontario municipalities. London, Ontario: University of Western Ontario.

Kallio, Christopher A. (1986). Regional and local roles in municipal economic development (MA Thesis). Waterloo: University of Waterloo. 
Keating, Michael. (1991). Comparative urban policies: Power and the city in the United States, Canada, Britain and France. Hants, UK: Edward Elgar Publishing Limited.

Kitchen, Harry M. (1985). The role of local governments in economic development. Toronto: Ontario Economic Council Discussion Paper Series.

McCabe, Tim. (2007). Economic development: Moving forward governance review, Organizational change, engagement with community and enhanced investment funding. Hamilton: City of Hamilton.

Myhal, Natalie. (1994). Existing rationales for agencies, boards and commissions. Agencies, Boards, and Commissions in Canadian Local Government. Toronto: Institute of Public Administration of Canada.

Peterson, Paul. (1981). City Limits. Chicago: University of Chicago Press.

Richardson, Dale \& Siegal, David Siegel. (1994). Agencies, boards, and commissions in Canadian local government. Toronto: Institute of Public Administration of Canada.

Siegel, David. (1994). The ABCs of Canadian local government: An overview“. Agencies, Boards, and Commissions in Canadian Local Government. Toronto: Institute of Public Administration of Canada.

Siegel, David. (1994). The appropriate use of agencies, boards and commissions. Agencies, Boards, and Commissions in Canadian Local Government. Toronto: Institute of Public Administration of Canada. 


\section{Appendix A}

\begin{tabular}{|c|c|c|c|c|}
\hline Municipality & 1999 & 2004 & 2009 & $\begin{array}{l}\text { Municipal } \\
\text { Status }\end{array}$ \\
\hline Ajax, Town of & Internal & Internal & - & Lower Tier \\
\hline Amherstburg, Town of & - & Internal & - & Lower Tier \\
\hline Aurora, Town of & - & Internal & Internal & Lower Tier \\
\hline Barrie, City of & Internal & Internal & Internal & Single Tier \\
\hline Belleville, City of & Internal & Internal & Internal & Single Tier \\
\hline *Bracebridge, Town of & Internal & Internal & Internal & Lower Tier \\
\hline $\begin{array}{l}\text { Bradford West Gwillimbury, } \\
\text { Town of }\end{array}$ & - & - & Internal & Lower Tier \\
\hline Brampton, City of & Internal & Internal & Internal & Lower Tier \\
\hline Brant, County of & - & - & Internal & Single Tier \\
\hline Brantford, City of & Internal & Internal & Internal & Single Tier \\
\hline Brockville, City of & Internal & Internal & Internal & Single Tier \\
\hline Burlington, City of & Internal & External & External & Lower Tier \\
\hline Caledon, Town of & Internal & Internal & Internal & Lower Tier \\
\hline Cambridge, City of & Internal & Internal & Internal & Lower Tier \\
\hline $\begin{array}{l}\text { Centre Wellington, } \\
\text { Township of }\end{array}$ & - & Internal & Internal & Lower Tier \\
\hline $\begin{array}{l}\text { Chatham-Kent, Municipality } \\
\text { of }\end{array}$ & Internal & Internal & Internal & Single Tier \\
\hline Clarence-Rockland, City of & - & - & - & Lower Tier \\
\hline Clarington, Municipality of & Internal & Internal & Internal & Lower Tier \\
\hline *Cobourg, Town of & Internal & Internal & Internal & Lower Tier \\
\hline Collingwood, Town of & Internal & Internal & Internal & Lower Tier \\
\hline Cornwall, City of & Internal & Internal & Internal & Single Tier \\
\hline East Gwillimbury, Town of & - & - & - & Lower Tier \\
\hline Essa, Township of & - & - & - & Lower Tier \\
\hline Essex, Town of & - & - & - & Lower Tier \\
\hline Fort Erie, Town of & External & External & External & Lower Tier \\
\hline Georgina, Town of & - & - & - & Lower Tier \\
\hline Greater Napanee, Town of & - & - & - & Lower Tier \\
\hline Greater Sudbury, City of & External & Internal & Internal & Single Tier \\
\hline Grimsby, Town of & Internal & Internal & Internal & Lower Tier \\
\hline Guelph, City of & Internal & Internal & Internal & Single Tier \\
\hline Haldimand County & Internal & Internal & Internal & Single Tier \\
\hline Halton Hills, Town of & - & Internal & Internal & Lower Tier \\
\hline Hamilton, City of & Internal & Internal & Internal & Single Tier \\
\hline
\end{tabular}




\begin{tabular}{|c|c|c|c|c|}
\hline Huntsville, Town of & Internal & Internal & Internal & Lower Tier \\
\hline Innisfil, Town of & - & Internal & Internal & Lower Tier \\
\hline Kawartha Lakes, City of & - & Internal & Internal & Single Tier \\
\hline Kenora, City of & - & - & Internal & Single Tier \\
\hline King, Township of & - & Internal & Internal & Lower Tier \\
\hline Kingston, City of & External & External & External & Single Tier \\
\hline Kingsville, Town of & - & - & Internal & Lower Tier \\
\hline Kitchener, City of & Internal & Internal & Internal & Lower Tier \\
\hline Lakeshore, Town of & - & - & - & Lower Tier \\
\hline LaSalle, Town of & - & - & - & Lower Tier \\
\hline Leamington, Municipality of & Internal & Internal & Internal & Lower Tier \\
\hline Lincoln, Town of & - & - & - & Lower Tier \\
\hline *London, City of & External & External & External & Single Tier \\
\hline Loyalist, Township of & - & - & - & Lower Tier \\
\hline Markham, Town of & Internal & Internal & Internal & Lower Tier \\
\hline Middlesex Centre, Mun. of & - & - & Internal & Lower Tier \\
\hline *Midland, Town of & $\begin{array}{l}\text { Outsource } \\
\text { d }\end{array}$ & $\begin{array}{l}\text { Outsource } \\
\text { d }\end{array}$ & Internal & Lower Tier \\
\hline Milton, Town of & Internal & Internal & Internal & Lower Tier \\
\hline Mississauga, City of & Internal & Internal & Internal & Lower Tier \\
\hline New Tecumseth, Town of & External & - & - & Lower Tier \\
\hline Newmarket, Town of & - & - & Internal & Lower Tier \\
\hline Niagara Falls, City of & Internal & Internal & Internal & Lower Tier \\
\hline Norfolk County & Internal & Internal & Internal & Single Tier \\
\hline *North Bay, City of & Internal & Internal & Internal & Single Tier \\
\hline Oakville, Town of & Internal & External & Internal & Lower Tier \\
\hline Orangeville, Town of & Internal & Internal & Internal & Lower Tier \\
\hline$*$ Orillia, City of & Internal & Internal & Internal & Single Tier \\
\hline Oro-Medonte, Township of & - & Internal & - & Lower Tier \\
\hline Oshawa, City of & Internal & Internal & Internal & Lower Tier \\
\hline Ottawa, City of & Internal & Internal & Internal & Single Tier \\
\hline Owen Sound, City of & Internal & Internal & Internal & Lower Tier \\
\hline Pelham, Town of & - & - & - & Lower Tier \\
\hline *Peterborough, City of & - & - & - & Single Tier \\
\hline Pickering, City of & Internal & Internal & Internal & Lower Tier \\
\hline Port Colborne, City of & Internal & Internal & External & Lower Tier \\
\hline Port Hope, Municipality of & - & Internal & Internal & Lower Tier \\
\hline $\begin{array}{l}\text { *Prince Edward County, City } \\
\text { of }\end{array}$ & External & Internal & Internal & Single Tier \\
\hline
\end{tabular}




\begin{tabular}{|c|c|c|c|c|}
\hline Quinte West, City of & Internal & Internal & Internal & Single Tier \\
\hline Richmond Hill, Town of & Internal & Internal & Internal & Lower Tier \\
\hline$*$ Sarnia, City of & Internal & Internal & Internal & Lower Tier \\
\hline Sault Ste. Marie, City of & External & External & External & Single Tier \\
\hline Scugog, Township of & - & - & - & Lower Tier \\
\hline $\begin{array}{l}\text { Smith-Ennismore-Lakefield, } \\
\text { Township }\end{array}$ & - & - & - & Lower Tier \\
\hline $\begin{array}{l}\text { South Frontenac, Township } \\
\text { of }\end{array}$ & - & - & - & Lower Tier \\
\hline Springwater, Township of & - & - & - & Lower Tier \\
\hline St. Catharines, City of & Internal & Internal & Internal & Lower Tier \\
\hline St. Thomas, City of & External & External & External & Single Tier \\
\hline Stratford, City of & Internal & Internal & Internal & Single Tier \\
\hline $\begin{array}{l}\text { Strathroy-Caradoc, } \\
\text { Township of }\end{array}$ & Internal & Internal & - & Lower Tier \\
\hline Tecumseh, Town of & - & - & - & Lower Tier \\
\hline Thorold, City of & Internal & - & - & Lower Tier \\
\hline *Thunder Bay, City of & Internal & Internal & Internal & Single Tier \\
\hline Timmins, City of & External & External & External & Single Tier \\
\hline Toronto, City of & Internal & Internal & Internal & Single Tier \\
\hline Uxbridge, Township of & - & - & - & Lower Tier \\
\hline Vaughan, City of & Internal & Internal & Internal & Lower Tier \\
\hline Wasaga Beach, Town of & Internal & Internal & Internal & Lower Tier \\
\hline Waterloo, City of & Internal & Internal & Internal & Lower Tier \\
\hline Welland, City of & Internal & Internal & Internal & Lower Tier \\
\hline Whitby, Town of & Internal & Internal & Internal & Lower Tier \\
\hline $\begin{array}{l}\text { Whitchurch-Stouffville, } \\
\text { Town of }\end{array}$ & Internal & Internal & Internal & Lower Tier \\
\hline Wilmot, Township of & - & Internal & Internal & Lower Tier \\
\hline Windsor, City of & - & - & - & Single Tier \\
\hline Woodstock, City of & Internal & Internal & Internal & Lower Tier \\
\hline Woolwich, Township of & - & Internal & Internal & Lower Tier \\
\hline
\end{tabular}

* Municipality was contacted for clarification 